\title{
The Influence of Conditions of The Hold In The Port To The Freshness of The Fish In Mayangan, Probolinggo and Port of Sendang Biru, East Java, Indonesia
}

\author{
Eddy Suprayitno \\ Faculty of Fisheries and Marine Science, Brawijaya University, Indonesia
}

\begin{abstract}
The hold is a room used as storage of fish on board. In conjunction with the ability to withstand the heat inside the hold, then hold the fish can be grouped up insulated hold and not insulated hold. The insulated hold divided into insulated hold with a refrigeration mechanic to cooling and refrigeration mechanic with clotting. The hold is part of ship fish which serves to store and maintain the condition of the fish. The size of the holdshould be large enoughto store the catch is optimum. Requirements on the hold, namely the design, construction and the type of material used shall follow the terms of the hold in order to secure the maximum possible catches. This study aimed to compare the condition of the hold contained on the ship in the port of Mayangan, Probolinggo and Sendang Biru Port, Malang, whereas the method used was descriptive method, by comparing the temperature, $p H$, and the levels of TMA as an indicator of freshness of fish.
\end{abstract}

Keywords: hold, ship, port

\section{Introduction}

Fishing port as an economic centre of fisheries is a vital component in the system of capture fisheries needs to be utilized, organized and managed as well-as good. Fish auction is a major activity in the fishing port which need to be managed optimally, since the activities of the auction is actually determined how big the sales receipt of the fishermen, who in the later stages, specify how quantities of income of fishermen(fishermen owners and fishermen labor) (Pane et al., 2009).

Function of fishing port is seen in terms of economic activity is the centre of activity fisheries are reviewed from the aspect of fish landing and unloading, processing, marketing and fishing port also serves as a place to create a market mechanism that is profitable for fishermen and traders. The activities of the fish auction in such activities then the fishing port is the initial activities of the marketing of fish to get a decent price (Lubis, 2000).

Fish landing base is where boats or ships landing, fisheries. The landing site was work environment fisheries economic activities which include the area of waters and land, in order to provide public services and services tostreamline the activities of the fishing vessel or boat and fishing effort (Pryaza, 2008).

The application of technology of insulated hold is crucial; given the fishery products is the commodity that quickly broke down, so handling should start from the very beginning, i.e. by applying cold chains ranging from fish raised to ship up to marketing. With the application of the cold chain is expected to fish quality can be maintained so that any value can be increased, which in turn can increase the income and welfare of fishermen (Erlina and Nendah, 2007).

The hold is a room used as storage of fish on board. In conjunction with the ability to withstand the heat inside the hold, then hold the fish can be grouped up insulated hold and not insulated hold. Insulated hold divided into insulated hold with a refrigeration mechanic to cooling and refrigeration mechanic with clotting (Lafi, 2004).

The hold is part of ship fish which serves to store and maintain the condition of the fish. The size of the hold should be large enough to store the catch is optimum. The Volume of the hold shall be calculated carefully, hold outrageously large will result in wastage and affect the motion of a ship at sea by. This is because at the time of the hold is full, a burdens borne by the outrageously large (Iskandar and Wazir, 1997).

According to Trimulyono and Muhammad (2011), a fish with payload of living became an alternative for fishermen to earn a high income for the life of the fishermen. The existence and use of systems to hold live fish, the fisherman can help reduce operational costs while preserving fish catches amounted to $11.8 \%$. Besides the quality and economic value catches will also rise, which will ultimately increase the level of welfare of fishermen.

According to Kurniawati (2004), the requirements on the hold, namely the design, construction and the type of material used shall follow the terms of the hold in order to secure the maximum possible catches. The construction and material of the hold should be qualified is the biological, technical, sanitary and hygiene, the economical and legal. Increased demand for fresh fish needs to be accompanied by improvements in the 
quality of the catch. The Unit catching the most influential in maintaining the quality of the catch was the ship. On the ship there is the hold that serves to keep the fish and is equipped with a cooling material to lower the temperature of the fish while keeping the temperature of the fish while keeping quality. With respect to the function of the hold should be qualified construction biologically, hygiene, sanitation, technical, economical and legal.

The existence and use of systems to hold live fish, is expected to help fishermen reduce operational costs while preserving the fish catches. Besides the quality and economic value catches will also rise, which will ultimately increase the level of welfare of fishermen. By using the system hold live fish to catch are expected also to conserve fisheries resources, because fishermen will be more selective in catching fish (Hadi et al., 2007)

Insulated hold is the place to keep of fish catches on the inside of the ship that blends with the body of the vessel, its walls made of casted polyurethane. Hold it like this is generally found on ships large fish (10 GT or more). Insulated hold is the hold the crate in the shape of a coffin ships to smallsized fish (5 GT), the crate walls casted with polyurethane. Insulated pen is not permanent, but rather can be removed from the board and was appointed to clean up (Bapertan, 1998).

\section{Research Methodology}

The method used is descriptive, whereas the method of collection and data retrieval is the primary data. Primary Data is data that is retrieved directly by observing directly against the object under investigation, both in the actual situation as well as in special artificial situation was held. So the primary data is obtained directly from the recording of observations, interviews, active participation and documentation.

The interview is the process of obtaining information for research purposes by way of question and answer, while face to face between answerer or questioner with the interviewer or respondents using a tool called the interview guide (guide interview).

This study aimed to compare the condition of the hold contained on the ship in the port of Mayangan, Probolinggo and port of Sendang Biru, Malang. Then it conducted measurements of temperature, $\mathrm{pH}$ and the levels of TMA as an indicator of freshness of fish.

\section{Results And Discussion}

\section{The Hold Condition in the Port of Mayangan, Probolinggo}

From the results of interviews conducted at the port of Mayangan, Probolinggo, obtained an explanation as follows; Form the hold must comply with the general principle and its use. Hold the ideal in General rectangular space with a spherical form follows the basic hulls or side. It aims to save the fish with a large enough capacity and maintain the quality of fish in order to stay well until on the Mainland.

Design, construction and material types hold used must follow the requirements in order to secure the maximum possible catches. Construction of the hold should qualify the biologically, that is able to suppress the growth of bacteria, and technically should be able to inhibit the flow of heat from the outside, the sanitation and hygiene the hold must be free from contamination, economically the hold must be made of strong materials, cheap, safe and durable, and be legally material types have to match quality standard.

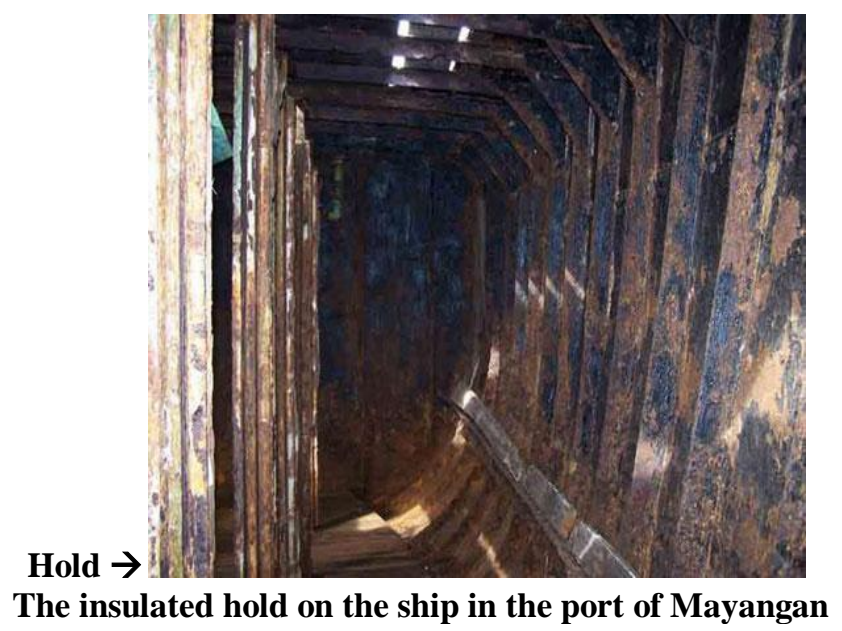

The hold type used on one of the ships in the port of Mayangan, Probolinggo is insulated and refrigerated hold. The hold is used which consists of an attachment of the hold, insulation and refrigeration. The hold designed because it aims to conserve and maintain the freshness of 
the fish on ice because it aims to conserve and maintain the freshness of the fish on ice because the ships used to locate fish and to market it to the outside area of Probolinggo. Moreover, it also can avoid the physical damage and chemical as well as biological processes that can degrade the quality of the fish. The temperature that can be achieved by refrigerated hold is $-5^{\circ} \mathrm{C}$, with a $\mathrm{pH}$ of 7 , and TMA on the fish in the hold of $12 \mathrm{mgN} / 100 \mathrm{~g}$. The cooling material of refrigerated hold is the Freon and can load up to 10 tones of fish.

\section{- The Hold Condition in Port of Sendang Biru, Malang}

From the results of interviews conducted in the Spring Harbor blue, retrieved some explanation as follows; the hold is a space in the vessel that is used to store the fish during the arrest operation. This type is used in the hold of the ship of medium size and long operation of about 7 to 15 days in a single operation. The hold is used consisting of several layers of the hold, among others; Zinc can slow down the process of melting of ice so that fish are stored where temperature remains stable. Then there is wood, there's also the hold that use plywood or fiber as a layer of wood substitutes, but the use of plywood or fiber is less effective because the ice is melting fast when compared to wood. Then after there is a sponge or wood cork and putty.

Sponge or Cork is a material with low heat conductivity of the insulation. So the use of a sponge in the hold can make the ice looking for longer, or slow down the process of melting ice. While the putty is used to create the exterior of the hold to be really close and minimize leakage.

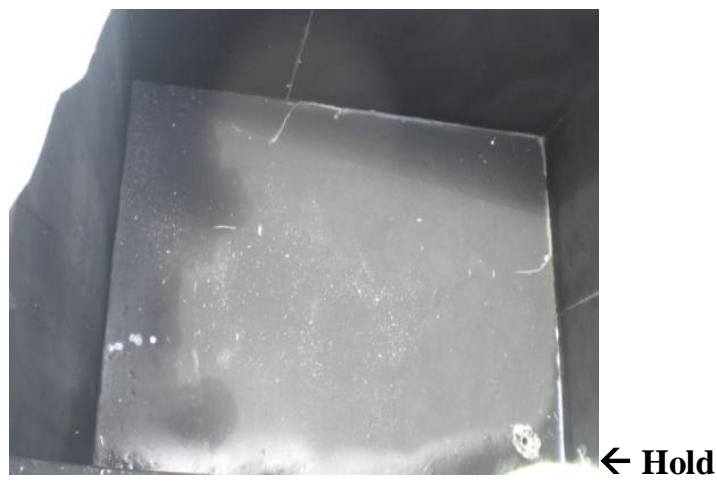

The hold condition on a ship in the port of Sendang Biru

Overall the hold on the ship in the port of Sendang Biru conditions are still decent, it can be used for 2 to 3 years, and a maximum of 5 years. The rest should be done repair or replacement in order to hold the hold can function properly. The hold type used on one of the ships in the port of the spring blue is the hold isolated without refrigeration system. The hold is used on a ship that we observe is composed of several layers of the hold, the innermost part of the wood, and then there are the hold after the wood there is a sponge or the cork, then putty on the very outside of the hold. Sponge or cork is a material with low heat conductivity of the insulation. So the use of a sponge in the hold can make the ice looking for longer, or slow down the process of melting ice.

The hold is structured in such a way aiming to conserve the use of ice as insulation on hold so the process of thawing the ice melting or can be slowed, but it can minimize the occurrence of damage-damage to physical, chemical, and microbiological as well as slowing down biochemical processes that lead to decay, so that the quality and the quality of the fish can be maintained.

The temperature that can be reached by refrigerated hold is not 4 the hold ${ }^{0} \mathrm{C}$, with a $\mathrm{pH}$ of 6.3 , and the TMA on the fish stored in the hold of $18 \mathrm{mgN} / 100 \mathrm{~g}$. The cooling material of refrigerated hold is ice and can contain up to $500 \mathrm{~kg}$ of fish.

- Comparison of temperature, Ph and Refrigerated Hold in the Port of Mayangan, Probolinggo and Non-Refrigerated Hold in the Port of Sendang Biru,Malang

Comparison of research results of temperature, $\mathrm{pH}$ and TMA on the fish in the refrigerated hold in the port of Mayangan, Probolinggo and non-refrigerated hold in the port of Sendang Biru are as follows.

\begin{tabular}{ccc}
\hline Parameter & $\begin{array}{c}\text { Port of Mayangan, Probolinggo } \\
\text { (Refrigerated Hold) }\end{array}$ & $\begin{array}{c}\text { Port of Sendang Biru, Malang } \\
\text { (Non-Refrigerated Hold) }\end{array}$ \\
\hline \multirow{2}{*}{ www.iosrjournals.org } & $60 \mid$ Page
\end{tabular}


The Influence Of Conditions Of The Hold In The Port To The Freshness Of The Fish In Mayangan,

\begin{tabular}{lcc}
\hline Temperature & $-5^{0} \mathrm{C}$ & $4^{0} \mathrm{C}$ \\
$\mathrm{pH}$ & 6,3 & 6,8 \\
TMA & $12 \mathrm{mgN} / 100 \mathrm{~g}$ & $18 \mathrm{mgN} / 100 \mathrm{~g}$ \\
\hline
\end{tabular}

Comparison chart of the temperature of the fish in the refrigerated hold in the port of Mayangan, Probolinggo and non-refrigerated hold in the port of Sendang Biru, Malang are as follows.

\section{Temperature}

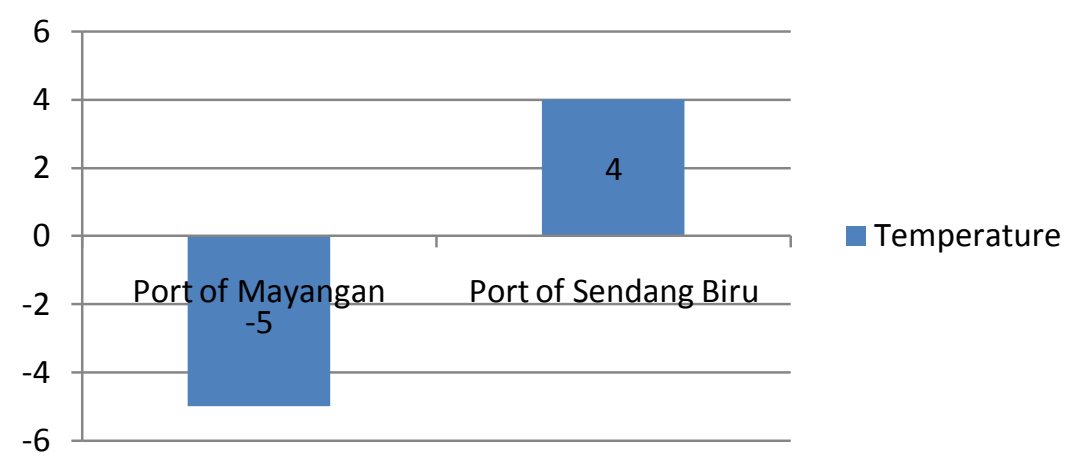

On the refrigerated hold, the temperature reached the fish surfaced $-5^{0} \mathrm{C}$, while in the non-refrigerated hold, the temperature of the fish is $4^{0} \mathrm{C}$. The lower temperature of the fish is then able to extend power durable fish. Advantages of preservation with freezing are the original properties of fish did not experience changes in texture, taste and smell (Adawyah, 2000).

Comparison chart of the $\mathrm{pH}$ of the fish in the refrigerated hold in the port of Mayangan, Probolinggo and non-refrigerated hold in the port of Sendang Biru, Malang are as follows.

\section{$\mathrm{Ph}$}

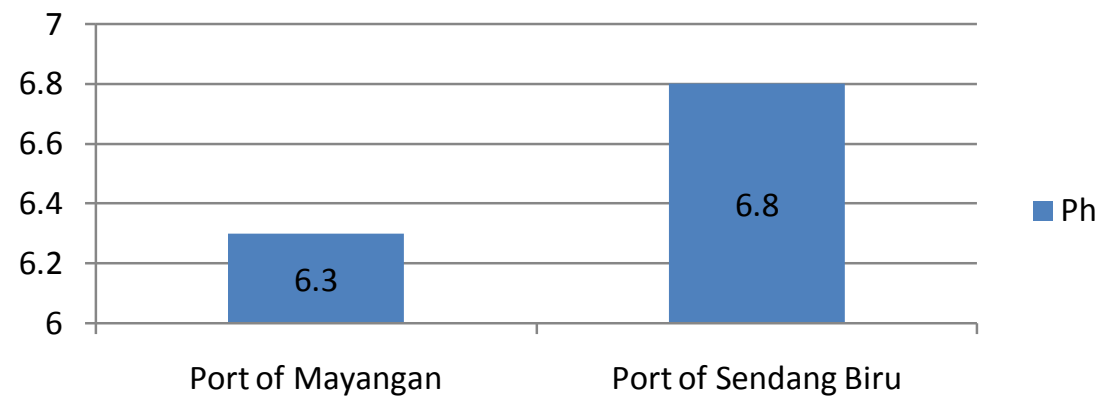

A pH value on the fish in the refrigerated hold was 6.3, while in the non-refrigerated hold had a $\mathrm{pH}$ of 6.8 fish. The $\mathrm{pH}$ value is one of the indicators used to determine the level of the freshness of the fish. On the process of decaying fish fish meat $\mathrm{pH}$ changes very big role because of the effect on the process of autolysis and bacterial assaults (Munandar, 2009).

Comparison chart of the TMA of the fish in the refrigerated hold in the port of Mayangan, Probolinggo and non-refrigerated hold in the port of Sendang Biru, Malang are as follows. 


\section{TMA}

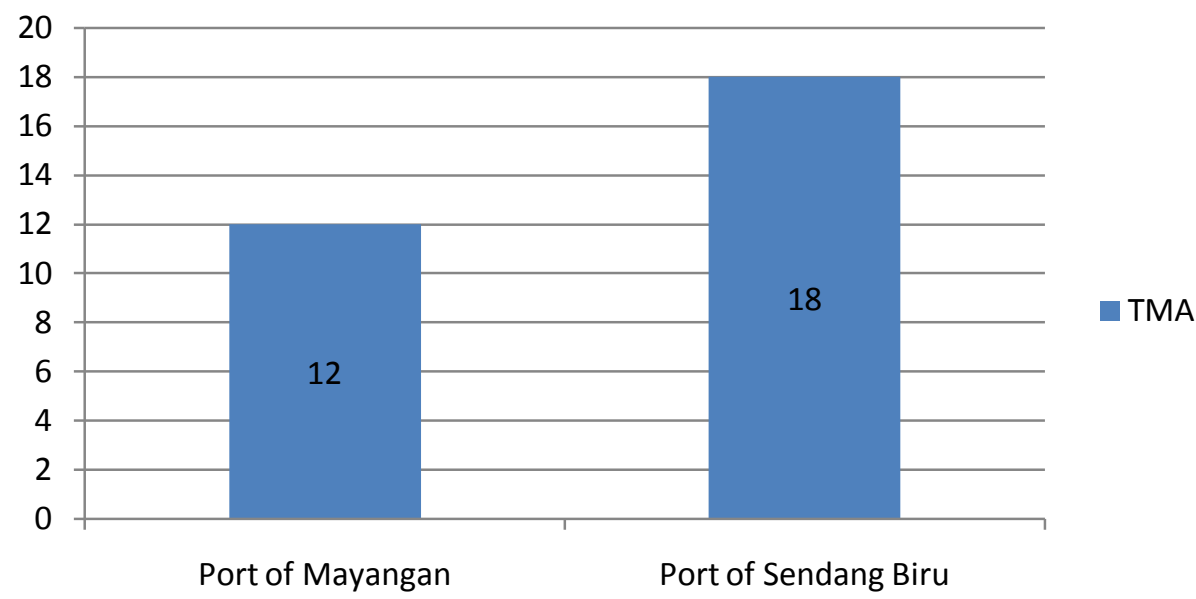

On the refrigerated hold, the levels of TMA in fish reaching $12 \mathrm{mgN} / 100 \mathrm{~g}$, where as in the nonrefrigerated hold, the levels of TMA in fish reaching $18 \mathrm{mgN} / 100 \mathrm{~g}$. Increasingly high levels of TMA increasingly ugly fish quality, because the levels of TMA-related degradation bacterial in fish flesh. As a quality standard of freshness of fish, then made the default value TMA as national standards, where the value of the fishery should not be of TMA $22.05 \mathrm{mgN} / 100 \mathrm{~g}$ (Murjiaharto, 2005).

\section{Conclusion}

Based on the results of the research there were differences, are known to hold the ship in the port of Mayangan, the town of Probolinggo and port of Sendang Biru, Malang. The hold on the ship in the port of Mayangan, Probolinggo was more modern and equipped by the refrigerator and isolation. While the hold on the ship in the port of Sendang Biru, Malang is still traditional. The hold is not equipped by refrigeration tools, smaller and use zinc or wood as an insulator.

\section{Reference}

[1]. Adawyah, R. 2000. Fish Processing and Preservation. Bumi Aksara. Jakarta

[2]. Bapertan. 1998. Making Container / Palka insulated. Agency for Agricultural Research and Development Installation Agricultural Research And Technology Assessment. Jakarta

[3]. Erlina, M.D. and N. Kurniasari. 2007. Technology Adoption Palka Insulated for Handling of Fresh Fish in Pelabuhan Ratu, Sukabumi. Journal of Fisheries (J. Fish. Sci) IX (2): 241-253 ISSN: 0853-6384.

[4]. Hadi, E.S., H. Boesono., P. Manik., andA.W.B Santosa. 2007. Fishing Vessel Design and Sustainable Multi Function: A New Concept Vehicle for Fishing Vessel in Eastern Indonesia Region. Diponegoro University. Semarang.

[5]. Iskandar, B.H, M. Wazir. 1997. Study On Fishing Vessel Capacity Palka On the North Coast and South West Java. Bogor Agricultural Institute. Bogor.

[6]. Kurniawati, V.R. 2004.Construction and Heat Load Calculation on Palka Fish Purse Seine in Pekalongan (for example in KM. Duta Mulia).Bogor Agricultural Institute. Bogor.

[7]. Lafi, L. 2004. The Shape and Volume Palka Tuna Longline GT Size Taiwan and Section 50-100 Type in PPS Jakarta.Bogor Agricultural Institute. Bogor.

[8]. Lubis, E. 2000.Introduction to Fishing Port.Bogor Agricultural University. Bogor.

[9]. Munandar, A. 2009. Quality Changes of Tilapia Fish (O. niloticus) by Killing Techniques and Gutting During Low Storage Temperature. Bogor Agricultural University. Bogor.

[10]. Murdjiharto. T. J. 2005. Fish Protein Nutritional Biochemistry.Brawijaya University. Malang

[11]. Pane, A.B, E. Lubis, T. Nugroho and M. Syahrir. 2009. Fish Auction Optimization Model in Fishery Harbour Fishermen in the Context of National Income. Proceedings of the Research Seminar.Bogor Agricultural University. Bogor.

[12]. Pryaza, H. 2008. Assessment Activity and Functional Capacity Facility In Fish Landing Base (Ppi) Kronjo. Faculty of Fisheries and Marine Sciences.Bogor Agricultural University. Bogor.

[13]. Trimulyono, A.and M. Iqbal. 2011. Analysis of Speed Boats Against the Effects of Changes in Fluid Systems in The Palka on Fishing Vessel Type Cargo Catamaran Living With CFD approach. Ship- Vol. 8, No. 2, June 2011. 